\title{
Olfactory Dysfunction in the COVID-19 Outbreak
}

\author{
Izquierdo-Dominguez $\mathrm{A}^{1,2,3, *}$, Rojas-Lechuga $\mathrm{MJ}^{4,5,6}$, Mullol J,5,6,** , Alobid I $\mathrm{I}^{2,4,5,6, *, * *}$ \\ 'Allergy Department, Consorci Sanitari de Terrassa, Barcelona, Spain \\ 'Unidad Alergo Rino, Centro Médico Teknon, Barcelona, Spain \\ ${ }^{3}$ Allergy Department, Clínica Diagonal, Barcelona, Spain \\ ${ }^{4}$ Rhinology Unit \& Smell Clinic, ENT Department, Hospital Clinic Barcelona, CIBERES, Universitat de Barcelona, Barcelona, Spain \\ ${ }^{5}$ Clinical \&t Experimental Respiratory Immunoallergy, IDIBAPS, Barcelona, Spain \\ ${ }^{6}$ CIBER of Respiratory Diseases (CIBERES), Barcelona, Spain \\ *These authors contributed as corresponding authors. \\ **These authors share senior author responsibilities.
}

J Investig Allergol Clin Immunol 2020; Vol. 30(5): 317-326

doi: 10.18176/jiaci.0567

\section{Abstract}

The first cases of coronavirus 2019 disease (COVID-19) occurred in Wuhan, China, and the disease rapidly become a public health emergency of international proportions. COVID-19 can cause mild-to-severe acute respiratory syndrome (SARS) and is caused by the SARS-CoV-2 coronavirus. The clinical manifestations of COVID-19 include fever, dry cough, fatigue, sputum production, shortness of breath, sore throat, and headache. We performed this narrative review to analyze the current literature on postviral olfactory dysfunction related to the SARSCoV-2 pandemic. Since the initial anecdotal reports from China, increasingly frequent international reports on COVID-19 indicate that $5 \%$ to $85 \%$ of affected patients lose their sense of smell, thus highlighting the very heterogeneous nature of the literature in this area. Therefore, we advise home isolation measures and/or social distancing, as well as tests to detect SARS-CoV-2 when possible, in patients with sudden and severe loss of smell who cannot be promptly evaluated.

Key words: Coronavirus. COVID-19. Taste disorder. Loss of smell. Anosmia. SARS-CoV-2.

\section{Resumen}

Los primeros casos de la enfermedad por coronavirus 2019 (COVID-19) ocurrieron en Wuhan, China, y se propagaron rápidamente para convertirse en una emergencia de salud pública y de preocupación internacional. La enfermedad puede manifestarse desde una forma leve a un síndrome respiratorio agudo grave (SARS) y es causada por el coronavirus SARS-CoV-2. Las manifestaciones clínicas de COVID-19 incluyen fiebre, tos seca, fatiga, expectoración, dificultad respiratoria, odinofagia y cefalea. El objetivo de este estudio es revisar la literatura actual sobre la disfunción olfatoria (DO) posviral en lo que respecta a la pandemia de SARS-CoV-2. Se han publicado un creciente número de estudios a nivel mundial desde los casos anecdóticos iniciales en China, en los que se ha demostrado una prevalencia variable de pérdida de olfato en pacientes COVID-19 que va desde un 5 a un 85\%. Hasta la fecha, la literatura es ampliamente heterogénea respecto a la pérdida de olfato, por lo que podemos advertir y recomendar a aquellos pacientes con pérdida del olfato súbita y grave que no puedan ser evaluados rápidamente, seguir medidas de aislamiento domiciliario y/o distanciamiento interpersonal, así como realizar pruebas de diagnóstico para el SARS-CoV-2 cuando sea posible.

Palabras clave: Coronavirus. COVID 19. Alteraciones del gusto. Pérdida del olfato. Anosmia. SARS-CoV-2. 


\section{Introduction}

The respiratory symptoms of coronavirus disease 19 (COVID-19), which is caused by the coronavirus SARSCov-2, are extremely heterogeneous, ranging from minimal to severe involvement that can progress rapidly to hypoxia and severe acute respiratory distress. The disease is very contagious and may be fatal. It is of the utmost importance to provide an early diagnosis focusing on alarming symptoms and thus avoid the spread of the virus. Sudden and severe olfactory dysfunction (OD), in the absence of other respiratory symptoms should alert physicians to COVID-19 infection.

The present narrative review aims to update current knowledge on the anatomy and physiology of olfactory pathways and to provide more details on the etiology of smell disorders and smell tests. We also discuss the role of OD as a diagnostic criterion and possible treatment in the context of the COVID-19 outbreak.

\section{Anatomy and Physiology of Smell}

Human sensory processes (sight, hearing, perhaps even taste and touch) are mostly well understood; however, we still do not fully understand smell, which remains an elusive sense. In fact, scientists have not been able to explain how the human body's odor can act as a scented fingerprint. Researchers from various fields are coming together to solve the mysteries of olfaction.

The perception of flavor is perhaps the most multisensory of our everyday experiences. Flavor involves a combination of gustatory and olfactory stimuli, with the interaction of other sensory modalities, such as trigeminal perception, sight, and hearing [1].

The perception of odor is based on orthonasal smell, which is the result of sniffing (eg, the aroma of food or the bouquet of wine), and retronasal smell, which is located within the oropharynx and results from airflow via the nasopharynx during swallowing or nasal exhalation. Apart from noticeable

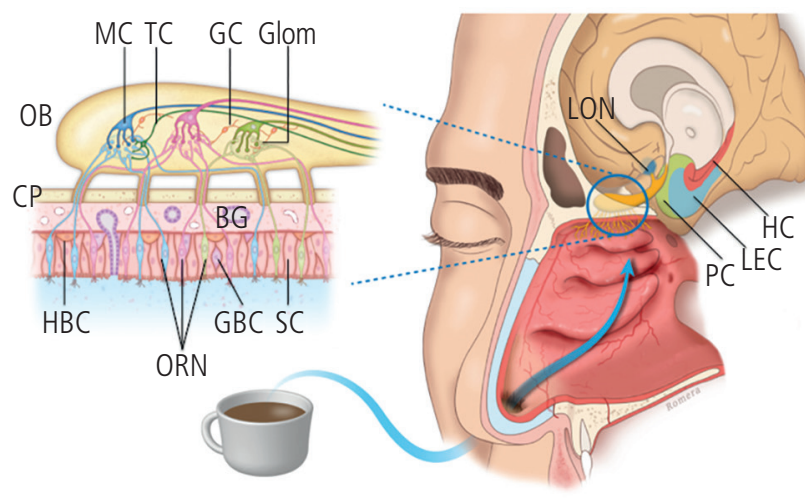

Figure 1. Human olfactory pathways. BG indicates Bowman gland; $G C$ granule cell; GBC, globose basal cell; Glom, glomerulus; HBC, horizontal basal cell; $\mathrm{HC}$, hippocampus; $C$, cribriform plate; LEC, lateral entorhinal cortex; LON, lateral olfactory nucleus; $\mathrm{MC}$, mitral cell; $\mathrm{OB}$, olfactory bulb; ORN, olfactory receptor neuron; PC, piriform cortex; TC, tufted cell; SC, sustentacular cell. deficiencies in detection based on chemical gustometry (sweet, sour/acidic, bitter, salty, and savory/umami), "taste" disorders most commonly reflect inadequate stimulation of the olfactory receptors in the retronasal route [2].

The human olfactory neuroepithelium constitutes $1.25 \%$ of the nasal mucosa and covers an 8 - to $10-\mathrm{cm}^{2}$ area composed of the cribriform plate, the upper part of the nasal septum, and the middle/upper turbinates (Figure 1). About 10 million of the dendrites of olfactory receptor neurons in the olfactory bulb project to the mucosa. The odorants reaching the olfactory epithelium dissolve in the mucus layer and bind/activate olfactory receptors through a complex interaction often requiring odorant-binding proteins. One odor is capable of activating multiple receptor types to varying degrees [3].

Olfactory sensory neurons transduce the chemical message into nerve impulse emission frequencies and send them to the olfactory glomeruli. Olfactory information is processed and integrated into the olfactory bulb. The axons of the olfactory bulb mitral cells successively cross the olfactory peduncle and olfactory tract before projecting onto the primary olfactory cortex. The information processed in the piriform cortex then projects to various brain areas: the orbitofrontal cortex, amygdala, hypothalamus, insula, entorhinal cortex, and hippocampus [4,5]. In humans, approximately 350 functional odorant genes encode specific protein receptors that interact with their own subset of chemicals or substances, leading to the complex mechanism of smell identification [6].

Furthermore, it is very important to know that neither the olfactory sensory neurons nor the olfactory bulb neurons express specific genes, which are instead expressed in support cells, stem cells, and perivascular cells. These findings suggest that infection of nonneuronal cells leads to anosmia and related disturbances in odor perception in patients $[7,8]$

\section{Etiology of the Loss of Smell}

OD can be classified as either quantitative, where the ability to recognize changes in the strength of an odor is altered, or qualitative, where the ability to recognize differences in the quality of an odor is altered. Normal olfactory function is termed normosmia; quantitative disorders are classified as hyposmia (decrease in smell) and anosmia (total lack of smell) [9,10]. Physiologically, our perception of smell changes with age, and while our ability to detect smells increases up to and peaks in the fourth decade of life, recognition and identification of smells decline significantly after the sixth decade [11].

OD plays an important role in daily living by influencing food selection and nutrient intake, enjoyment of food, socialization, overall quality of life, and detection of safety hazards from food poisoning and toxic agents [9]. Several studies have shown that olfactory impairment can affect quality of life and may lead to depression [12]. Therefore, any improvement in our sense of smell can be considered a potential antidepressant [13].

Many disease states are associated with OD, including congenital causes, postinfectious disorders, sinonasal diseases, traumatic brain injuries, and neurodegenerative disorders. We can make a series of specific observations as follows: 
- In congenital anosmia (olfactory bulb hypoplasia or aplasia), Kallmann syndrome (hypogonadotropic hypogonadism) and Turner syndrome (absence of all or part of one X chromosome) should be ruled out $[14,15]$.

- Postviral upper respiratory infection could be due to a combined conductive and sensorineural/inflammatory disorder [16].

- Sinonasal diseases, such as allergic rhinitis and rhinosinusitis, can cause conductive and inflammatory disorders, which act as anatomic barriers that prevent odorants from reaching the olfactory epithelium and receptors $[5,17]$.

- Neurodegenerative diseases, such as Alzheimer disease and Parkinson disease, are sensorineural disorders that arise from deficient reception or processing of a stimulus by the olfactory receptors, olfactory neurons, or central pathways to centers of olfaction in the central nervous system (CNS) [18-20].

- Traumatic head injuries are sensorineural disorders often overlooked by patients and their caregivers owing to the focus on initial stabilization and treatment [21-23].

The association between OD and smoking remains controversial, and negative and positive effects have been reported [24]. However, smoking cessation seems to improve both rated and measured olfactory function. A recent study of 3900 patients with loss of smell found that 521 were current smokers and 316 former smokers. The authors concluded that patients with a history of smoking did not have a significantly diminished olfactory function [25].

Additionally, multiple pharmacological treatments are related to OD. A study of a large sample by Lötsch et al [26] identified an association between antagonistic targeting of adrenoceptor $\alpha$ 1A (ADRA1A) and higher olfactory scores. It has been demonstrated that ADRA1A is the most common target among all those affected by the drugs reportedly influencing human olfaction, and it has been suggested that adrenergic activation enhances inhibitory transmission in the olfactory system. In addition, long-term treatments with aminoglycosides and tetracyclines and any use of opioids, cannabinoids, or sildenafil are known to affect olfaction [26].

Other types of medication that influence olfaction are potassium-sparing diuretics, antiplatelet drugs, $\alpha$ - and $ß$-blockers, and calcium channel blockers. It may be that potassium-sparing diuretics interfere with olfactory receptor activity because they comprise a large class of $\mathrm{G}$ proteincoupled receptors that, once activated, are capable of triggering neuronal activity [27].

Ottaviano et al [28] found that the number of drugs taken (polypharmacotherapy) was significantly correlated with greater olfactory loss in elderly patients.

\section{Smell Tests}

Several techniques and tools are available to explore olfactory capacity, each with advantages and disadvantages. It is important to note that of all these methods (mainly subjective reporting via a visual analog scale and psychophysical, neurophysiological, and neuroimaging techniques) are complementary because they do not measure the same olfactory parameters, functions, or processes. Psychophysical testing by a trained specialist to identify and discriminate between odors and set cut-off points is highly recommended for detection of the severity of OD and to follow up on the progression/reversal of the loss of smell (Table 1).

In the research setting, combined psychophysical and electrophysiological tests have been developed to quantify olfactory ability with functional magnetic resonance imaging [29] and electro-olfactogram [30]. The limitations of these tests are that they cannot discriminate reliably between the causes of OD and provide no information about the site of lesions.

\section{COVID Pandemic}

During the past 2 decades, we have experienced 2 fatal coronavirus outbreaks: severe acute respiratory syndrome (SARS) in 2002 and Middle East respiratory syndrome (MERS) in 2012. COVID-19 has swept across the world, creating a pandemic that has led to more than 2 million cases diagnosed $(2,471,136$ as April 22, 2020) and almost 170,000 deaths [31].

Table 1. List of Validated Subjective Olfactory Diagnosis Tests

University of Pennsylvania Smell Identification Test (UPSIT)

Connecticut Chemosensory Clinical Research Center Test (CCCRC)

Smell Diskettes Olfaction Test (SDT)

Odorant confusion matrix (OCM)

Dutch odor identification test (GITU)

YN-odour Identification Test (YN-OIT)

T\&T Olfactometer

San Diego Odor Identification Test (SDOIT)

Cross-Cultural Smell Identification Test (CC-SIT)

Combined olfactory test (COT)

Sniffin' Sticks

Candy Smell Test (CST)

Alcohol Sniff Test (AST)

Culturally adjusted UPSIT (CA-UPSIT)

Kremer smell test (KST)

Scandinavian Odor-Identification Test (SOIT)

Pocket Smell Test (PST)

Eloit and Trotier Olfactory Test (ETOT)

Four-minute odour identification test

Barcelona Smell Test (BAST-24)

Nez du Vin smell test

Paediatric Barcelona Olfactory Test-6 (pBOT-6)

Universal Sniff Test (U-sniff), for children

Visual analog scale (VAS, $0-10 \mathrm{~cm}$ ) for loss of smell or taste 
Transmission is thought to occur mainly from the spread of large droplets that carry virus particles. However, under certain circumstances, such as coughing, the particles can become aerosolized or airborne, thus increasing the risk of spread. The virus may also be transmitted via body fluids, direct contact, and possible fecal-oral contact [32].

Transmission is mainly by symptomatic patients. However, a larger incubation period (which can last longer than 14 days) and asymptomatic shedding can exacerbate the infectivity of the virus, resulting in a large number of carriers [33]. The combination of high transmissibility and absence of symptoms contributes to rapid spread [30-36].

Given that COVID-19 is a newly emerging infectious disease, it is critical to understand and identify the key clinical characteristics of affected patients in order to improve early detection, isolate infected individuals, and minimize the spread of the disease. Based on a recent metaanalysis (38 studies involving 3062 COVID-19 patients in China), the most common symptoms were fever, fatigue, cough, dyspnea, expectoration, and, less often, rhinorrhea or sore throat. A relatively small percentage of patients were asymptomatic (11\%) [33]. Common laboratory findings include lymphocytopenia and increased values of C-reactive protein, lactate dehydrogenase, D-dimer, and erythrocyte sedimentation rate. Bilateral lung involvement has been shown to be common on chest X-ray and chest computed tomography scans $[32,37]$. SARS-CoV-2 infection is currently diagnosed using the reverse transcription polymerase chain reaction (RT-PCR) assay to determine nucleic acid sequence homology in nasopharyngeal or throat swabs [38].

Symptomatic infection (susceptibility) and outcome (fatality) are closely associated with age. Compared with persons aged 30-59 years, those aged below 30 and above 59 years were 0.6 and 5.1 times more likely to die after developing symptoms, revealing that the risks of symptomatic infection increased with age (eg, $4 \%$ per year among adults aged 30-60 years) [39]. Clinical outcomes were poorer in the case of comorbidities, such as circulatory diseases including hypertension, coronary heart disease, and or diabetes [40].

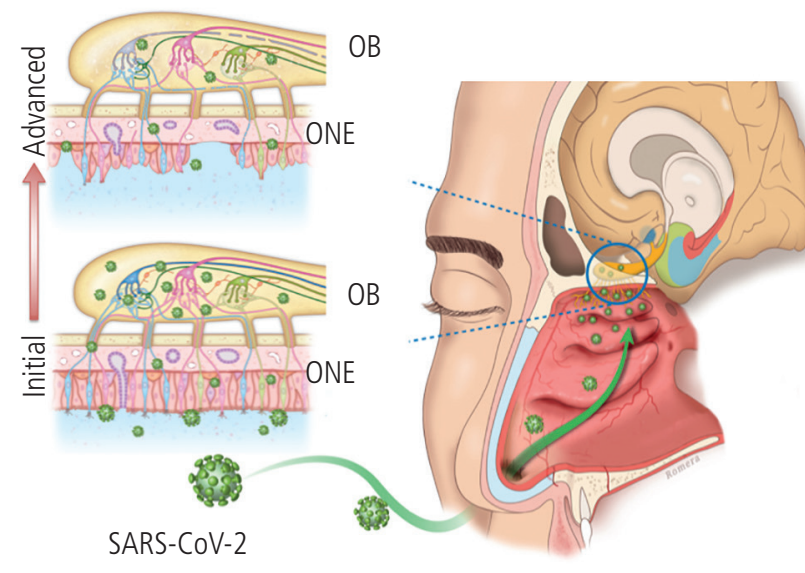

Figure 2. Potential mechanism of induced neurodegenerative effects of SARS-CoV-2 coronavirus in human olfactory pathways. OB indicates olfactory bulb; ONE, olfactory neuroepithelium.

\section{COVID 19 and Olfactory Dysfunction}

Olfactory dysfunction is well documented in viral infections. Many viruses may lead to OD through an inflammatory reaction of the nasal mucosa and subsequent development of rhinorrhea. The main causal agents are rhinovirus, parainfluenza virus, Epstein-Barr virus, and some coronaviruses. Spontaneous improvement rates after upper respiratory infection stand at 35\%-67\%. Follow-up of postviral olfactory loss revealed that over $80 \%$ of patients reported subjective recovery after 1 year [41]. The exact pathophysiology of postviral OD is not well understood. No specific upper respiratory symptoms allow COVID-19 to be reliably distinguished from other types of viral respiratory infections.

The respiratory epithelium is the primary site of SARSCoV-2 attachment and infection, as is the case in many other respiratory viruses. Therefore, it is not surprising that COVID-19 affects the olfactory neuroepithelium, with an impact on smell and flavor [42]. Our team recently demonstrated that 2 out of 3 patients with the common cold or postviral acute rhinosinusitis have impaired smell, which is associated with disease severity [16].

In January 2020, angiotensin-converting enzyme 2 (ACE2) was identified as the functional receptor for SARS-CoV-2. ACE2 is present in multiple human organs, including the CNS and skeletal muscles. The expression and distribution of ACE2 remind us that SARS-CoV-2 can cause neurologic manifestations through direct or indirect mechanisms. Autopsy results of patients with COVID-19 showed that the brain tissue was hyperemic and edematous and that some neurons were degenerated [43].

Neurologic injury has been confirmed in infection by other coronaviruses, such as SARS-CoV and MERS-CoV. Researchers detected SARS-CoV-2 nucleic acid in the cerebrospinal fluid of patients and also in their brain tissue on autopsy. The virus can enter the CNS through a hematogenous or retrograde neuronal route [44] (Figure 2). Previous studies have shown the ability of SARS-CoV to cause neuronal death in mice by invading the brain via the nose close to the olfactory epithelium [45].

Since the initial anecdotal reports from China, an increasing number of international reports of COVID-19 patients report loss of smell in 5\% to $85 \%$ of patients (Table 2 ). A study from Iran based on online surveys showed a significant increase in new-onset anosmia since the COVID-19 outbreak [42]. Researchers found a strong correlation between the number of self-reported anosmia/hyposmia cases and COVID-19 cases. A subsequent survey in confirmed COVID-19 patients reported an $87 \%$ prevalence of olfactory impairment [42].

Vaira et al [46] studied 320 COVID-19 patients and found anosmia in $19.4 \%$, although they did not report the method used to determine how loss of smell was measured.

A study from China reported that only $5.1 \%$ and $5.6 \%$ of hospitalized patients complained, respectively, of loss of smell and loss of taste [44]. The authors described 3 categories of neurological manifestations: CNS manifestations (dizziness, headache, impaired consciousness, acute cerebrovascular disease, ataxia, and seizure), peripheral nervous system 
Table 2. Summary of Published Data on Olfactory and Taste Dysfunction After SARS-CoV-2 Infection

\begin{tabular}{|c|c|c|c|c|c|c|c|}
\hline Author & Country & $\begin{array}{l}\text { Patient, } \\
\text { No. }\end{array}$ & $\begin{array}{c}\text { Female, } \\
\%\end{array}$ & $\begin{array}{l}\text { Mean } \\
\text { (SD/range) } \\
\text { age, y }\end{array}$ & $\begin{array}{l}\text { COVID-19- } \\
\text { Positive }\end{array}$ & Study Design & $\begin{array}{l}\text { Effect on Smell } \\
\text { and Taste, \% }\end{array}$ \\
\hline $\begin{array}{l}\text { Bagheri } \\
\text { et al [42] }\end{array}$ & Iran & 10069 & 71.1 & $32.5(8.6)$ & - & $\begin{array}{l}\text { Cross-sectional } \\
\text { Self-reported online checklist }\end{array}$ & Loss of smell, 87 \\
\hline $\begin{array}{l}\text { Mao } \\
\text { et al [44] }\end{array}$ & China & 214 & 59.3 & $52.7(15.5)$ & 214 & $\begin{array}{l}\text { Retrospective, observational } \\
\text { case series. Electronic medical } \\
\text { records, laboratory and } \\
\text { radiologic findings }\end{array}$ & $\begin{array}{l}\text { Loss of smell, } 5.1 \\
\text { Loss of taste, } 5.6\end{array}$ \\
\hline $\begin{array}{l}\text { Menni } \\
\text { et al [47] }\end{array}$ & UK & 1702 & 69 & 40.8 & 579 & Cross-sectional & $\begin{array}{l}\text { Loss of smell } \\
\text { and taste, } 59.4\end{array}$ \\
\hline $\begin{array}{l}\text { Heidari } \\
\text { et al [51] }\end{array}$ & Iran & 23 & 65 & 37.4 & 23 & Case-series & Loss of smell, 83 \\
\hline $\begin{array}{l}\text { Levinson } \\
\text { et al [52] }\end{array}$ & Israel & 45 & 45.2 & $\begin{array}{l}\text { Median, } 34 \\
\quad(15-82)\end{array}$ & 42 & Cross-sectional & Loss of smell, 35.7 \\
\hline $\begin{array}{l}\text { Giacomelli } \\
\text { et al [53] }\end{array}$ & Italy & 59 & 32.2 & $60(50-74)$ & 59 & $\begin{array}{l}\text { Cross-sectional } \\
\text { Self-reported smell and taste } \\
\text { loss (questionnaire) }\end{array}$ & $\begin{array}{l}\text { At least loss of } \\
\text { smell or taste, } 33.9 \\
\text { Both, } 18.6\end{array}$ \\
\hline $\begin{array}{l}\text { Gudbjartsson, } \\
\text { et al [54] }\end{array}$ & Iceland & 4551 & 47.7 & $40.3(18.4)$ & 528 & Population-based & Loss of smell, 11.5 \\
\hline $\begin{array}{l}\text { Benezit, } \\
\text { et al [55] }\end{array}$ & France & 259 & - & - & 68 & Cross-sectional & $\begin{array}{l}\text { Loss of smell, } 45 \\
\text { Loss of taste, } 62\end{array}$ \\
\hline Yan et al [56] & USA & 1480 & 49 & $\begin{array}{c}\text { Stratified by } \\
\text { decade (18-79) }\end{array}$ & 102 & $\begin{array}{l}\text { Cross-sectional } \\
\text { Subjective olfaction score } \\
\text { of } 1-10\end{array}$ & $\begin{array}{l}\text { Loss of smell, } 68 \\
\text { Loss of taste, } 71\end{array}$ \\
\hline $\begin{array}{l}\text { Klopfenstein } \\
\text { et al [57] }\end{array}$ & France & 114 & 67 & $47(16)$ & 54 & Retrospective observational & $\begin{array}{l}\text { Loss of smell, } 47 \\
\text { Loss of taste, } 85\end{array}$ \\
\hline $\begin{array}{l}\text { Spinato } \\
\text { et al [58] }\end{array}$ & Italy & 202 & 52 & $\begin{array}{l}\text { Median, } 56 \\
(20-89)\end{array}$ & 202 & $\begin{array}{l}\text { Cross-sectional } \\
\text { Sinonasal Outcome test } 22 \\
\text { (SNOT-22) }\end{array}$ & $\begin{array}{l}\text { Loss of smell and } \\
\text { taste, } 64.4\end{array}$ \\
\hline $\begin{array}{l}\text { Wee } \\
\text { et al [59] }\end{array}$ & Singapore & 870 & - & - & 154 & $\begin{array}{l}\text { Cross-sectional } \\
\text { Self-reported loss of smell } \\
\text { and taste }\end{array}$ & $\begin{array}{l}\text { Loss of smell and } \\
\text { taste, } 22.7\end{array}$ \\
\hline $\begin{array}{l}\text { Lechien } \\
\text { et al [60] }\end{array}$ & $\begin{array}{l}\text { Belgium, } \\
\text { Spain, Italy, } \\
\text { France }\end{array}$ & 417 & 63.1 & $36.9(11.4)$ & 417 & $\begin{array}{l}\text { Prospective multicenter } \\
\text { Questionnaire of Olfactory } \\
\text { Disorders-Negative Statements } \\
\text { (sQOD-NS) }\end{array}$ & $\begin{array}{l}\text { Loss of smell, } 85 \\
\text { Loss of taste, } 88\end{array}$ \\
\hline $\begin{array}{l}\text { Kaye } \\
\text { et al [61] }\end{array}$ & $\begin{array}{l}\text { US, Italy, } \\
\text { Mexico, UK }\end{array}$ & 240 & 54 & $\begin{array}{l}39.6(14.6) \\
(2-89)\end{array}$ & 237 & Cross-sectional & Loss of smell, 73 \\
\hline $\begin{array}{l}\text { Moein } \\
\text { et al [62] }\end{array}$ & Iran & 60 & 33 & $46.5(12.2)$ & 60 & $\begin{array}{l}\text { Case-control } \\
\text { Psychophysical test: University } \\
\text { of Pennsylvania Smell } \\
\text { Identification Test (UPSIT) }\end{array}$ & $\begin{array}{l}\text { Loss of smell, } 12 \\
\text { Loss of taste, } 7 \\
\text { Both, } 17\end{array}$ \\
\hline
\end{tabular}

manifestations (taste impairment, smell impairment, vision impairment, and nerve pain), and skeletal muscle injury. However, the data were retrospectively collected from medical files. Therefore, the real prevalence may have been underestimated, because these symptoms might not be spontaneously reported if not searched for.

A study from the United Kingdom including 579 COVID-19-positive and 1123 COVID-19-negative patients revealed that loss of smell and taste $(59.4 \%)$ is a strong predictor of having been infected by the COVID-19 virus [47].
Gane et al [48] correlated the number of diagnosed cases of COVID-19 in the United Kingdom with the increase in sudden anosmia, as reported on social media during the early days of the pandemic. Sudden complete loss of smell was subsequently reported in a patient without nasal obstruction. Sinus computed tomography and magnetic resonance imaging scans revealed bilateral inflammation of the olfactory clefts, with normal olfactory bulbs and tracts [49]. Villalba et al [50] described 2 elderly patients evaluated in the emergency department for anosmia/ 
dysgeusia in the absence of any other respiratory symptoms. Clinical and biological workups led to a diagnosis of COVID-19 infection.

A case series $(n=23)$ from Iran showed OD in $83 \%$ of patients [51]. Another study $(n=42)$ from Israel reported the condition in $35.7 \%$ [52].

The first European study included 59 hospitalized patients in Italy; 20 patients $(33.9 \%)$ reported at least taste or olfactory disorders, and $11(18.6 \%)$ reported both symptoms. Twelve patients $(20.3 \%)$ had the symptoms before admission, whereas 8 (13.5\%) experienced the symptoms during their hospital stay [53].

In a population-based study in Iceland, $528(11.5 \%)$ COVID-19 patients had OD [54]. In France, Benezit et al [55] found that of 68 COVID-19 patients, $45 \%$ were affected.

Yan et al [56] included a total of 1480 patients from the USA with influenza-like symptoms who underwent COVID-19 testing. Loss of smell and loss of taste were reported in $68 \%$ and $71 \%$ of COVID-19-positive patients $(n=59)$, respectively, compared with $16 \%$ and $17 \%$ of COVID-19-negative patients $(\mathrm{n}=203)(P<.001)$.

Klopfenstein et al [57] analyzed 114 confirmed cases of COVID-19 from France and reported anosmia in 47\%, together with dysgeusia in $85 \%$. Anosmia was never the first or second symptom to develop, but the third in $38 \%$ of cases. Anosmia developed 4.4 days after onset of infection. Similar results from Italy $(n=202)$ showed anosmia in $64.4 \%$ of cases [58].

In a study performed in Singapore, Wee et al [59] concluded that self-reported OD had high specificity as a screening criterion for COVID-19 in an Asian cohort (154). Patients with COVID-19 were more likely to experience the condition $(27.7 \%)$ than patients who were positive for other respiratory viruses.

A total of 417 COVID-19 patients from 12 European hospitals were included in a multicenter study conducted in France, Belgium, Italy, and Spain. Researchers reported that $85.6 \%$ had OD (79.6\% anosmia and $20.4 \%$ hyposmia), with an impact on quality of life, and $88.8 \%$ had gustatory disorders. Onset of OD was before (11.8\%), after $(65.4 \%)$, or at the same time as that of general ear, nose, and throat symptoms (22.8\%). OD linked to COVID-19 infection attracts special interest because it is not associated with rhinorrhea [60].

Similarly, an international cross-sectional study by Kaye et al [61] with 237 COVID-19 patients reported OD in $73 \%$.

Given the limitations associated with the transmissibility of the disease and emergency contingencies, it is impossible to administer a structured questionnaire and validated smell tests. Future studies using well-validated instruments to assess olfaction will play a key role in corroborating patientreported subjective assessments of OD. To date, smell has been quantitatively assessed in only 1 study (University of Pennsylvania Smell Identification Test), which demonstrated that $98 \%$ of COVID-19 patients $(n=60)$ exhibited some smell dysfunction, $33 \%$ had severe hyposmia, and $58 \%$ had anosmia (Table 1) [62].

Nasal biopsies from patients with postviral anosmia are characterized by extensive cicatrization, decreased numbers of receptor cells, absent or fewer cilia on remaining receptor cells, and replacement of sensory epithelium with respiratory epithelium [63]. However, in the absence of a complete olfactory assessment (smell test and nasal endoscopy), the precise etiology of COVID-19 remains undetermined. The response to a clinical outbreak necessarily requires the adoption of strict control of infection, as well as personal protective equipment and practices to minimize the risk of infection [64]. Personal protective equipment is rarely used in daily practice and can be cumbersome, uncomfortable, and stressful to wear.

Theoretically, procedures based on RT-PCR are able to detect even a small number of viral RNA particles in biological samples. However, in practice, for technical reasons, the biological material collected must have a much higher viral load to ensure a reliable diagnosis. Biopsy of the olfactory epithelium could serve as a tissue source for early detection of the virus and thus minimize false-negative test results [65].

Two possibilities seem likely. During an upper respiratory infection, it is common to experience some loss of smell as a result of nasal inflammation, mucosal edema, and obstruction of airflow into the olfactory cleft. Alternatively, the patient could develop postviral anosmia syndrome, with direct infection and inflammation of the olfactory mucosa and neurodegeneration of the olfactory sensory neurons. Damage to the peripheral nervous system and its subsequent dysfunction, with anosmia or hyposmia, could be a relevant indicator of disease progression $[66,67]$.

\section{Treatment of Postviral Anosmia}

The medical community is rapidly accruing information, and standards are likely to change quickly with newly reported results. We must learn from one another as the disease crosses the globe in order to integrate the lessons learned into clinical practice.

Postviral anosmia is the most common cause of OD, and while several treatments have been presented in the literature, there is no strong evidence for any pharmacologic treatment of postviral anosmia [68]. Similarly, we could address OD during the COVID-19 era as though it were postviral anosmia, taking into account that there is no specific treatment. Therefore, we should follow the same recommendations and management.

Treatment strategies depend upon the affected regions in the olfactory pathways. In cases of frank oral, nasal, or intracranial involvement, rational straightforward approaches to treatment are often available. In cases where damage to the sensory pathways is secondary to chronic inflammatory disease, trauma, viral invasion, toxic exposure, or unknown causes, the direction for therapy is more challenging [63].

\section{Corticosteroids}

Topical and systemic corticosteroids improve olfaction in patients with chronic rhinosinusitis [69]. Ethmoid tissue eosinophilia is associated with OD in nasal polyps, independently of disease severity. These results suggest a possible role for eosinophils or eosinophil-associated cytokines in loss of smell associated with chronic rhinosinusitis.

However, for OD that is not related to sinonasal disease and with no overt evidence of nasal inflammation, the exact treatment options are not well investigated. Studies testing the efficacy of therapies for postviral OD, including corticosteroids, report conflicting evidence. The benefit of corticosteroids is 
less clear, but physicians still commonly use them as firstline therapy. Corticosteroids are hypothesized to improve olfactory function through their anti-inflammatory effects and regulation of the sodium-potassium-adenosine triphosphate enzyme found in olfactory receptor neurons [70]. A recent systematic review suggests using corticosteroid rinses to improve olfactory outcomes in selected patients, with weaker evidence supporting the use of oral corticosteroids. Topical corticosteroid sprays do not improve OD in this patient population and are not recommended [71]. On the other hand, reports have demonstrated that the use of corticosteroids may escalate COVID-19 infection. The systematic review and meta-analysis by Yang et al [72] concluded that corticosteroids are associated with increased lung injury, shock, and mortality in patients with COVID-19-related pneumonia. Although intranasal corticosteroids are not recommended for sudden and severe smell loss in COVID-19 patients taking these drugs for the treatment of sinonasal diseases, such as rhinitis or chronic rhinosinusitis, discontinuation is not advised [73].

\section{Olfactory Training}

It is well known that in patients without OD, threshold sensitivity improves as a result of exposure to odorants and/ or repeated testing. Clinical studies report that systematic exposure to odorants or "olfactory training" may be beneficial to some persons with hyposmia or anosmia [74-76].

Damm et al [77] conducted a randomized, controlled, multicenter study and concluded that olfactory training is safe and seems particularly useful in patients who start within 12 months after the onset of OD. The patient's condition improves with this approach, and the use of odors at higher concentrations facilitates the improvement. The authors recommend olfactory training as a first successful therapeutic regimen in patients with postviral anosmia.

\section{Vitamins}

Vitamin A (b-carotene or retinol) is a potential treatment for loss of smell. The initial use of vitamin A in the chemical senses was based upon the idea that a pigmented epithelium is critical for olfactory transduction. Intranasal vitamin A at a dose of $10000 \mathrm{IU} / \mathrm{d}$ for 2 months may be useful in the treatment of postinfectious olfactory loss [78].

\section{Concluding Remarks and Recommendations}

Sudden and severe olfactory or taste dysfunction, in the absence of other respiratory diseases, such as allergic rhinitis, acute rhinosinusitis, or chronic rhinosinusitis, should alert physicians to COVID-19 infection. Assessing the sense of smell in these patients may help to identify patients requiring quarantine and/or early treatment. A fast-moving pandemic demands equally agile research techniques using real-time data collection. Assessing loss of smell with subjective selfreported or psychophysical tests could help the early detection of infected patients and reduce the number of carriers, thus preventing the spread of the virus. Given the heterogeneous nature of data reported in the literature since the beginning of the COVID-19 outbreak, we advise home isolation measures and/or social distancing, as well as diagnostic tests for SARS$\mathrm{CoV}-2$ when possible in patients with sudden and severe loss of smell. Olfactory training, as a treatment, may be beneficial for some patients with permanent loss of smell after COVID-19.

\section{Funding}

The authors declare that no funding was received for the present study.

\section{Conflicts of Interest}

Isam Alobid has acted as a consultant for Roche, Novartis, Mylan, Menarini, and MSD.

Joaquim Mullol has participated in national and international advisory boards and received speaker's fees and funding for clinical trials and research projects from ALK, AstraZeneca, Genentech, GlaxoSmithKline, Glenmark, Menarini, Mitsubishi-Tanabe, MSD, Mylan-MEDA Pharma, Novartis, Regeneron Pharmaceuticals, SANOFI-Genzyme, UCB Pharma, and Uriach Group.

The remaining authors declare that they have no conflicts of interest.

\section{References}

1. Liu DT, Besser G, Renner B, Seyferth S, Hummel T, Mueller CA. Retronasal olfactory function in patients with smell loss but subjectively normal flavor perception. Laryngoscope. 2019;130(7):1629-33.

2. Doty RL. Olfactory dysfunction and its measurement in the clinic. World J Otorhinolaryngol Head Neck Surg. 2015;1(1):2833.

3. Godoy MD, Voegels RL, Pinna Fde R, Imamura R, Farfel JM. Olfaction in neurologic and neurodegenerative diseases: a literature review. Int Arch Otorhinolaryngol. 2015;19(2):1769.

4. Patel RM, Pinto JM. Olfaction: anatomy, physiology, and disease. Clin Anat. 2014;27(1):54-60.

5. Mullol J, Mariño-Sánchez F, Valls M, Alobid I, Marin C. The sense of smell in chronic rhinosinusitis. J Allergy Clin Immunol. 2020 Mar; 145(3):773-6.

6. Garcia-Esparcia $P$, Schlüter $A$, Carmona $M$, Moreno J, Ansoleaga B, Torrejón-Escribano B, et al. Functional genomics reveals dysregulation of cortical olfactory receptors in Parkinson disease: novel putative chemoreceptors in the human brain. J Neuropathol Exp Neurol. 2013;72(6):524-39.

7. Yan CH, Faraji F, Prajapati DP, Ostrander BT, DeConde AS. Self-reported olfactory loss associates with outpatient clinical course in Covid-19. Int Forum Allergy Rhinol. 2020;10(7):82131.

8. Brann HD, Tsukahara T, Weinreb C, Lipovsek M, Van den Berge K, Gong B, et al. Non-neuronal expression of SARS-CoV-2 entry genes in the olfactory system suggests mechanisms underlying COVID-19-associated anosmia. bioRxiv 2020.03.25.009084). doi: https://doi.org/10.1101/2020.03.25.009084.

9. Hummel T, Whitcroft KL, Andrews $P$, Altundag A, Cinghi $C$, Costanzo RM, et al. Position paper on olfactory dysfunction. Rhinol Suppl 2017;54:1-30. 
10. Boesveldt S, Postma EM, Boak D, Welge-Luessen A, Schöpf $V$, Mainland JD, et al. Anosmia-A Clinical Review. Chem Senses. 2017;42(7):513-23.

11. Mullol J, Alobid I, Mariño-Sánchez F, Quintó L, de Haro J, Bernal-Sprekelsen $\mathrm{M}$, et al. Furthering the understanding of olfaction, prevalence of loss of smell and risk factors: a population-based survey (OLFACAT study). BMJ Open. 2012;2(6):e001256.

12. Rochet M, El-Hage W, Richa S, Kazour F, Atanasova B. Depression, Olfaction, and Quality of Life: A Mutual Relationship. Brain Sci. 2018;8(5):E80.

13. Wang F, Wu X, Gao J, Li Y, Zhu Y, Fang Y. The relationship of olfactory function and clinical traits in major depressive disorder. Behav Brain Res. 2020;386:112594.

14. Stamou MI, Georgopoulos NA. Kallmann syndrome: phenotype and genotype of hypogonadotropic hypogonadism. Metabolism. 2018;86:124-34.

15. Ros C, Alobid I, Centellas S, Balasch J, Mullol J, Castelo-Branco C. Loss of smell but not taste in adult women with Turner's syndrome and other congenital hypogonadisms. Maturitas. 2012;73(3):244-50.

16. Jaume F, Quintó L, Alobid I, Mullol J. Overuse of diagnostic tools and medications in acute rhinosinusitis in Spain: a population-based study (the PROSINUS study). BMJ Open. 2018;8(1):e018788.

17. Scangas GA, Bleier BS. Anosmia: Differential diagnosis, evaluation, and management. Am J Rhinol Allergy. 2017;31(1):3-7.

18. Marin C, Vilas D, Langdon C, Alobid I, López-Chacón $M$, Haehner A, et al. Olfactory Dysfunction in Neurodegenerative Diseases. Curr Allergy Asthma Rep. 2018;18(8):42.

19. Holbrook EH, Leopold DA. An updated review of clinical olfaction. Curr Opin Otolaryngol Head Neck Surg. 2006;14:23-8.

20. Doty RL, Hawkes $\mathrm{CH}$. Chemosensory dysfunction in neurodegenerative diseases. Handb Clin Neurol. 2019; 164:325-60.

21. Langdon C, Alobid I, Quinto L, Valero A, Picado C, Marin C, Mullol J. Self-perception of olfactory dysfunction is associated with history of Traumatic Brain Injury: post-hoc analysis from the OLFACAT survey. Rhinology. 2019;57(6):460-8.

22. Marin C, Laxe S, Langdon C, Alobid I, Berenguer J, Fuentes M, et al. Olfactory Training Prevents Olfactory Dysfunction Induced by Bulbar Excitotoxic Lesions: Role of Neurogenesis and Dopaminergic Interneurons. Mol Neurobiol. 2019;56(12):8063-75.

23. Howell J, Costanzo RM, Reiter ER. Head trauma and olfactory function. World J Otorhinolaryngol Head Neck Surg. 2018;4(1):39-45.

24. Glennon SG, Huedo-Medina T, Rawal S, Hoffman HJ, Litt MD, Duffy VB. Chronic Cigarette Smoking Associates Directly and Indirectly with Self-Reported Olfactory Alterations: Analysis of the 2011-2014 National Health and Nutrition Examination Survey. Nicotine Tob Res. 2019;21(6):818-27.

25. Fjaeldstad AW, Ovesen T, Hummel T. The Association Between Smoking on Olfactory Dysfunction in 3,900 Patients With Olfactory Loss. Laryngoscope. 2020 Feb 25. doi: 10.1002/ lary. 28552.

26. Lötsch J, Daiker H, Hähner A, Ultsch A, Hummel T. Drug-target based cross-sectional analysis of olfactory drugs effects. Eur J Clin Pharmacol. 2015;71:461-71.
27. Ottaviano G, Zuccarello D, Frasson G, Scarpa B, Nardello E, Foresta $C$, et al. Olfactory sensitivity and sexual desire in young adult and elderly men: an introductory investigation. Am J Rhinol Allergy. 2013;27:157-61.

28. Ottaviano G, Savietto E, Scarpa B, Bertocco A, Maculan P, Sergi $G$, et al. Influence of number of drugs on olfaction in the elderly. Rhinology. 2018;56:351-7.

29. Gottfried JA. Structural and functional imaging of the olfactory system. In: Doty RL, ed. Handbook of Olfaction and Gustation. Hoboken, NJ: John Wiley \& Sons Inc; 2015:279e304.

30. Gudziol H, Guntinas-Lichius O. Electrophysiologic assessment of olfactory and gustatory function. Handb Clin Neurol. 2019; 164:247-62.

31. Coronavirus disease 2019 (COVID-19): situation report-93. Geneva: World Health Organization reports. https://www. who.int/emergencies/diseases/novel-coronavirus-2019/ situation-reports Accessed April 22, 2020

32. Vukkadala N, Qian ZJ, Holsinger FC, Patel ZM, Rosenthal E. COVID-19 and the otolaryngologist - preliminary evidencebased review. Laryngoscope. 2020. Mar 26. doi: 10.1002/ lary. 28672

33. Wu Z, McGoogan JM. Characteristics of and Important Lessons From the Coronavirus Disease 2019 (COVID-19) Outbreak in China: Summary of a Report of 72314 Cases From the Chinese Center for Disease Control and Prevention. JAMA. 2020;323(13):1239-42

34. Ceccarelli M, Berretta M, Venanzi Rullo E, Nunnari G, Cacopardo B. Differences and similarities between Severe Acute Respiratory Syndrome (SARS)-CoronaVirus (CoV) and SARS-CoV-2. Would a rose by another name smell as sweet? Eur Rev Med Pharmacol Sci. 2020;24(5):2781-3.

35. Lai CC, Wang JH, Ko WC, Yen MY, Lu MC, Lee CM, et al. COVID-19 in long-term care facilities: An upcoming threat that cannot be ignored. Long-term Care Infection Prevention and Control. J Microbiol Immunol Infect. 2020;53(3):444-6.

36. Zhang J, Wu S, Xu L. Asymptomatic carriers of COVID-19 as a concern for disease prevention and control: more testing, more follow-up. Biosci Trends. 2020;14(3):206-8.

37. Zhu J, Ji P, Pang J, Zhong Z, Li H, He C, et al. Clinical characteristics of 3,062 COVID-19 patients: a meta-analysis. J Med Virol. 2020 Apr 15:10.1002/jmv.25884. doi: 10.1002/ jmv. 25884

38. Wang $X$, Tan L, Wang X, Liu W, Lu Y, Cheng L, Sun Z. Comparison of nasopharyngeal and oropharyngeal swabs for SARS-CoV-2 detection in 353 patients received tests with both specimens simultaneously. Int J Infect Dis. 2020;94:107-9.

39. Wu JT, Leung $K$, Bushman $M$, Kishore $N$, Niehus $R$, de Salazar PM, et al. Estimating clinical severity of COVID-19 from the transmission dynamics in Wuhan, China. Nat Med. 2020;26(4):506-10.

40. Guan WJ, Liang WH, Zhao Y, Liang HR, Chen ZS, Li YM, et al. Comorbidity and its impact on 1590 patients with Covid-19 in China: A Nationwide Analysis. Eur Respir J. 2020;55(5):2000547.

41. Lee DY, Lee WH, Wee JH, Kim JW. Prognosis of postviral olfactory loss: follow-up study for longer than one year. Am J Rhinol Allergy. 2014;28(5):419-22.

42. Bagheri SHR, Asghari AM, Farhadi M, Shamshiri AR, Kabir A, Kamrava SK, et al. Coincidence of COVID-19 Epidemic and 
Olfactory Dysfunction Outbreak. medRxiv. 2020. doi: https:// doi.org/10.1101/2020.03.23.20041889

43. Li SR, Tang ZJ, Li ZH, Liu X. Searching therapeutic strategy of new coronavirus pneumonia from angiotensin-converting enzyme 2: the target of COVID-19 and SARS-CoV. Eur J Clin Microbiol Infect Dis. 2020;39(6):1021-6.

44. Mao L, Jin H, Wang M, Hu Y, Chen S, He Q, et al. Neurologic Manifestations of Hospitalized Patients With Coronavirus Disease 2019 inWuhan, China. JAMA Neurol. 2020;77(6):68390.

45. Netland J, Meyerholz DK, Moore S, Cassell M, Perlman S. Severe acute respiratory syndrome coronavirus infection causes neuronal death in the absence of encephalitis in mice transgenic for human ACE2. J Virol. 2008;82(15):7264-75.

46. Vaira LA, Salzano G, Deiana G, De Riu G. Anosmia and Ageusia: Common Findings in COVID-19 Patients. Laryngoscope. 2020;130(7):1787.

47. Menni C, Valdes A, Freydin MB, Ganesh S, El-Sayed Moustafa J, Visconti A, et al. Loss of smell and taste in combination with other symptoms is a strong predictor of COVID-19 infection. Nature Medicine. doi: 10.1038/s41591-020-0916-2

48. Gane SB, Kelly C, Hopkins C. Isolated sudden onset anosmia in COVID-19 infection. A novel syndrome? Rhinology. 2020;58(3):299-301.

49. Eliezer $M$, Hautefort $C$, Hamel AL, Verillaud $B$, Herman $P$, Houdart E, Eloit C. Sudden and Complete Olfactory Loss Function as a Possible Symptom of COVID-19. JAMA Otolaryngol Head Neck Surg. 2020;146(7):674-5.

50. Villalba NL, Maouche Y, Ortiz MBA, Sosa ZC, Chahbazian JB, Syrovatkova A, et al. Anosmia and Dysgeusia in the Absence of Other Respiratory Diseases: Should COVID-19 Infection Be Considered? Eur J Case Rep Intern Med. 2020;7(4):001641.

51. Heidari F, Karimi E, Firouzifar M, Khamushian P, Ansari R, Mohammadi Ardehali $\mathrm{M}$, et al. Anosmia as a prominent symptom of COVID-19 infection. Rhinology. 2020;58(3):3023.

52. Levinson $R$, Elbaz $M$, Ben-Ami $R$, Shasha $D$, Levinson $T$, Choshen $G$, et al. Time course of anosmia and dysgeusia in patients with mild SARS-CoV-2 infection. Infect Dis (Lond). 2020;52(8):600-2.

53. Giacomelli A, Pezzati L, Conti F, Bernacchia D, Siano M, Oreni $L$, et al. Self-reported olfactory and taste disorders in SARS-CoV-2 patients: a cross-sectional study. Clin Infect Dis. 2020;71(15):889-90.

54. Gudbjartsson DF, Helgason A, Jonsson $H$, Magnusson OT, Melsted P, Norddahl GL, et al. Spread of SARS-CoV-2 in the Icelandic Population. N Engl J Med. 2020;382(24):2302-15.

55. Bénézit $F$, Turnier $P L$, Declerck $C$, Paillé $C$, Revest $M$, Dubée $V$, Tattevin P. Utility of hyposmia and hypogeusia for the diagnosis of COVID-19. Lancet Infect Dis. 2020;20(9):1014-5.

56. Yan CH, Faraji F, Prajapati DP, Boone CE, DeConde AS. Association of chemosensory dysfunction and Covid-19 in patients presenting with influenza-like symptoms. Int Forum Allergy Rhinol. 2020;10(7):806-13.

57. Klopfenstein T, Kadiane-Oussou NJ, Toko L, Royer PY, Lepiller Q, Gendrin V, et al. Features of anosmia in COVID-19. Med Mal Infect. 2020;50(5):436-9.

58. Spinato G, Fabbris C, Polesel J, Cazzador D, Borsetto D, Hopkins C, et al. Alterations in Smell or Taste in Mildly
Symptomatic Outpatients With SARS-CoV-2 Infection. JAMA. 2020;323(20):2089-90.

59. Wee LE, Chan YFZ, Teo NWY, Cherng BPZ, Thien SY, Wong $H M$, et al. The role of self-reported olfactory and gustatory dysfunction as a screening criterion for suspected COVID-19. Eur Arch Otorhinolaryngol. 2020;277(8):2389-90.

60. Lechien JR, Chiesa-Estomba CM, De Siati DR, Horoi M, Le Bon SD, Rodriguez A, et al. Olfactory and gustatory dysfunctions as a clinical presentation of mild-to-moderate forms of the coronavirus disease (COVID-19): a multicenter European study. Eur Arch Otorhinolaryngol. 2020;277(8):2251-61.

61. Kaye R CC, Kazahaya K, Brereton J, Denneny III JC. COVID-19 anosmia reporting tool: initial findings. Otolaryngol Head Neck Surgery. 2020;163(1):132-4.

62. Moein ST, Hashemian SMR, Mansourafshar B, Khorram-Tousi A, Tabarsi P, Doty RL. Smell dysfunction: a biomarker for COVID-19. Int Forum Allergy Rhinol. 2020;10(8):944-50.

63. Doty RL. Treatments for smell and taste disorders: A critical review. Handb Clin Neurol. 2019;164:455-79.

64. Wong CS, Tay WC, Hap XF, Chia FL. Love in the time of coronavirus: training and service during COVID-19. Singapore Med J. 2020;61(7):384-6.

65. Butowt R, Bilinska K. SARS-CoV-2: Olfaction, Brain Infection, and the Urgent Need for Clinical Samples Allowing Earlier Virus Detection. ACS Chem Neurosci. 2020;11(9):1200-3.

66. Trotier D, Bensimon JL, Herman P, Tran Ba Huy P, Doving KB, Eloit C. Inflammatory Obstruction of the Olfactory Clefts and Olfactory Loss in Humans: A New Syndrome? 2006;32(3):28592.

67. Besser G, Liu DT, Renner B, Hummel T, Mueller CA. Reversible obstruction of the olfactory cleft: impact on olfactory perception and nasal patency. Int Forum Allergy Rhinol. 2020;10(6):713-8.

68. Harless L, Liang J. Pharmacologic treatment for postviral olfactory dysfunction: a systematic review. Int Forum Allergy Rhinol. 2016;6(7):760-7.

69. Banglawala SM, Oyer SL, Lohia S, Psaltis AJ, Soler ZM, Schlosser RJ. Olfactory outcomes in chronic rhinosinusitis with nasal polyposis after medical treatments: a systematic review and meta-analysis. Int Forum Allergy Rhinol. 2014;4(12):98694.

70. Fong KJ, Kern RC, Foster JD, Zhao JC, Pitovski DZ. Olfactory secretion and sodium, potassium-adenosine triphosphatase: regulation by corticosteroids. Laryngoscope. 1999;109:383-8.

71. Yan $\mathrm{CH}$, Overdevest JB, Patel ZM. Therapeutic use of steroids in non-chronic rhinosinusitis olfactory dysfunction: a systematic evidence-based review with recommendations. Int Forum Allergy Rhinol. 2019;9(2):165-76.

72. Yang Z, Liu J, Zhou Y, Zhao X, Zhao Q, Liu J. The effect of corticosteroid treatment on patients with coronavirus infection: a systematic review and meta-analysis. J Infect. 2020;81(1):e13-e20.

73. Bousquet J, Akdis C, Jutel M, Bachert C, Klimek L, Agache I, et al. Intranasal corticosteroids in allergic rhinitis in COVID-19 infected patients: An ARIA-EAACI statement. Allergy. 2020. Mar 31. doi: 10.1111/all.14302.

74. Patel ZM. The evidence for olfactory training in treating patients with olfactory loss. Curr Opin Otolaryngol Head Neck Surg. 2017;25(1):43-6. 
75. Sorokowska A, Drechsler E, Karwowski M, Hummel T. Effects of olfactory training: a meta-analysis. Rhinology. 2017;55(1):1726.

76. Hummel T, Rissom K, Reden J, Hähner A, Weidenbecher $M$, Hüttenbrink KB. Effects of olfactory training in patients with olfactory loss. Laryngoscope. 2009;119(3):496-9.

77. Damm M, Pikart LK, Reimann H, Burkert S, Göktas Ö, Haxel $B$, et al. Olfactory training is helpful in postinfectious olfactory loss: a randomized, controlled, multicenter study. Laryngoscope. 2014;124(4):826-31.

78. Hummel T, Whitcroft KL, Rueter G, Haehner A. Intranasal vitamin $A$ is beneficial in post-infectious olfactory loss. Eur Arch Otorhinolaryngol. 2017;274(7):2819-25.
- Manuscript received April 26, 2020; accepted for publication May 14, 2020.

- Adriana Izquierdo-Dominguez

Consorci Sanitari de Terrassa

Calle Torrebonica s $\mathrm{n}$

08227 Barcelona, Spain

E-mail: adrianaeizquierdo@hotmail.com

\section{Isam Alobid}

Hospital Clinic

Calle Villarroel 170

08035 Barcelona, Spain

E-mail: isamalobid@gmail.com 